\title{
動静脉瘦閉鎖後の未梢循環系および心の変動
}

九州大学整形外科

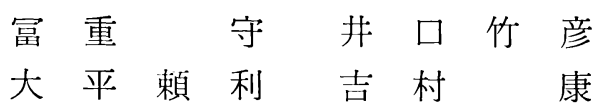

\section{Experimental Studies on Peripheral Circulation and Heart with Closed Arteriovenous Fistula}

\author{
By
}

M. Tomishige, T. Inokuchi, Y. Ōhira

\& Y. Yoshimura

Department of Orthopedic Surgery, Faculty of Medicine, Kyushu University

\footnotetext{
Femoral arteriovenous fistula (AVF) was performed and closed after a month in the dogs.

Follow up studies were carried out on blood flow, blood pressure, angiogram, diameter of blood vessel and cardio-thoracic rate (CTR).

The results obtained were mainly as follows:

1. Increased blood flow of femoral artery decreased considerably and blood pressure increased after closure of AVF.

2. Dilated proximal femoral artery recovered during three or four weeks after closure of AVF.

3. Increased CTR recovered within four weeks after closure of AVF.

4. Increased collateral vessels decreased after closure of AVF.
}

動静脉㜢 のある下肢の周径増大を報告したのは 1953 年 Giraldes が最初である. その後動静脉瘦を作 成して骨長径成長を目的とした臨床的および実験的な 報告がみられる，冨重らは動静脉瘦之骨発育抢よび未 梢循環について実験的および臨床的な詳細な報告を行 っている

今回は 実験的大腿動静脉瘦 を作成して 1 ケ月後こ れを閉鎖し循環系および心の変動を観察したので報告 する.

\section{実 験 方 法}

$5 \sim 15 \mathrm{~kg}$ の体重の犬にネンブタール腹腔内注入麻 酔のもとに $5 \mathrm{~mm}, 10 \mathrm{~mm}, 15 \mathrm{~mm}, 20 \mathrm{~mm}, 30 \mathrm{~mm}$ の吻合口の大腿動静脉隼を樑大腿動脉分岐部の未梢に て作成 1 ケ月後吻合口の中枢执よび未梢大腿静脉を結 紮して閉鎖し血流量, 血圧, 血管造影, 血管径, 心胸 郭係数 (CTR) などを比較検討した.
血流量はメラ電磁型血流量計（FMI-102），血圧は 電気血生計(MP-4 型)で吻合部附近にて測定した. 血 管造影は開腹して腹部大動脉より $60 \%$ ウログラフィ ン20４0 cc を注入して行い血管径は手術に上る刺激 で収縮した時期を出来るだけさけて測定した。また管 球とフイルム間距離 $1.2 \mathrm{~m}$ で胸部 X線をとり C.T.R. を算出した.

\section{実 験 結 果}

まず結禁閉銷前に吻合部を指尖部にて庄迫して血流 量と血圧の変化を観察した．中枢大腿動脉の分時平均 流量は著明に減少し血圧は上昇する．未梢大腿動脉で は血流量は症例によりととなるがやや減少例が多い。 中枢打よび未梢大腿静脉では血流量, 血圧共著明な低 下がみられ未梢大腿静脉では流れの方向が変化する. 健側大腿動脉では僅加に血流量. 血圧の増加がみられ 健側大腿動脉では血流量にはほとんど変化なく血圧は 
呴合部压追1823 帘化
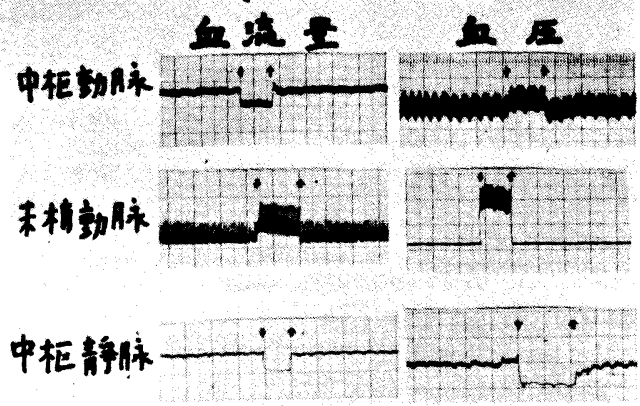

标样脉
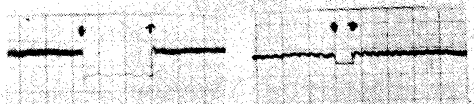

健湖动永
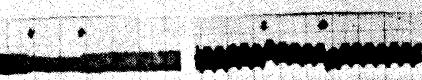

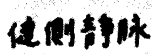

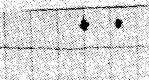

図 1

かに低下する例が多かった。（図 1 )圧迫により脉搏数 の減少がみられる例があった。

結禁閉鎖により中枢大腿動脉分時平均流量は閉鎖前 の 1/3〜1/20 亿娍少し血圧は上昇してほぼ吻合作成前 の血流量, 血圧に復する. その後 $8 \sim 16$ 週 まで著明 な変化を認めない。

未梢大腿動脉では閉鎖により血流量は減少する例 が多い。吻合口の大きい例で 1 ケ月後も 逆方向の流 れを示すむのがあり閉鎖により 流れの方向が 変化す る(図 2 ).

吻合作成後 1 ケ月の血管造影では動脉血が中枢およ び未梢静脉内に流入する像と共に豊富な小血管の陰影 像をみとめる．また総腸骨動脉大腿動脉の拡張がみら れる. 閉鎖直後では総腸骨動脉大腿動脉の拡張はなお 認められ小血管の陰影像は閉鎖により娍少するが健側 に比較するとやや多い. 閉鎖後 4 週では総腸骨動脉, 大腿動脉の拡張はないが健側に比して小血管の陰影像 がやや多い，閉鎖後 11 週も同様である（図 3 ).

吻合部附近の血管径は吻合作成により中枢大腿動脉 は拡張し 1 ケ月後はさらに著明となる．未梢大蹆動脉 では吻合作成直後は変化がないかまたは縮小するもの
図 2

（A）中枢大腿動脈分時平均流量 $(\mathrm{cc} / \mathrm{m})$

\begin{tabular}{|c|c|c|c|c|}
\hline & $\begin{array}{c}\text { 作成後 } \\
1 \text { 力月 }\end{array}$ & 閉鎖㨁後 & 閉 & 後 \\
\hline $5 \mathrm{~mm}$ & $\begin{array}{l}201 \\
425 \\
125\end{array}$ & $\begin{array}{l}20 \\
33 \\
19\end{array}$ & $\begin{array}{l}16(8 w) \\
29(4 w) \\
11(2 w)\end{array}$ & $28(16 w)$ \\
\hline $10 \mathrm{~mm}$ & $\begin{array}{l}325 \\
125\end{array}$ & $\begin{array}{l}25 \\
41\end{array}$ & $\begin{array}{l}20(8 w) \\
45(24 h)\end{array}$ & $16(3 w)$ \\
\hline $15 \mathrm{~mm}$ & $\begin{array}{l}131 \\
237\end{array}$ & $\begin{array}{l}30 \\
39\end{array}$ & $53(1 \mathrm{w})$ & \\
\hline $20 \mathrm{~mm}$ & $\begin{array}{l}160 \\
375 \\
178\end{array}$ & $\begin{array}{l}38 \\
78 \\
18\end{array}$ & $\begin{array}{l}42(1 \mathrm{w}) \\
42(2 \mathrm{w}) \\
25(3 \mathrm{w})\end{array}$ & $\begin{array}{l}26(8 w) \\
21(4 w) \\
35(16 w)\end{array}$ \\
\hline $25 \mathrm{~mm}$ & $\begin{array}{l}215 \\
283\end{array}$ & $\begin{array}{l}32 \\
20\end{array}$ & $\begin{array}{l}26(4 w) \\
18(4 w)\end{array}$ & \\
\hline $30 \mathrm{~mm}$ & $\begin{array}{l}175 \\
610\end{array}$ & $\begin{array}{l}58 \\
30\end{array}$ & $\begin{array}{l}21(8 \mathrm{w}) \\
25(1 \mathrm{w})\end{array}$ & $33(16 w)$ \\
\hline
\end{tabular}

（B）末梢大腿動脈分時平均流量 $(\mathrm{cc} / \mathrm{m})$

\begin{tabular}{|c|c|c|c|c|}
\hline & $\begin{array}{l}\text { 作成後 } \\
1 \text { 力月 }\end{array}$ & 閉銷㨁後 & 閉 & 後 \\
\hline $5 \mathrm{~mm}$ & $\begin{array}{l}25 \\
98 \\
38\end{array}$ & $\begin{array}{l}13 \\
33 \\
19\end{array}$ & $\begin{array}{l}12(8 w) \\
26(4 w) \\
12(2 w)\end{array}$ & $24(16 w)$ \\
\hline $10 \mathrm{~mm}$ & $\begin{array}{r}8 \\
25\end{array}$ & $\begin{array}{l}41 \\
24\end{array}$ & $\begin{array}{l}46(24 h) \\
21(8 w)\end{array}$ & $16(3 w)$ \\
\hline $15 \mathrm{~mm}$ & $\begin{array}{r}39 \\
-46\end{array}$ & $\begin{array}{l}16 \\
29\end{array}$ & $33(1 \mathrm{w})$ & \\
\hline $20 \mathrm{~mm}$ & $\begin{array}{r}-50 \\
50 \\
-24\end{array}$ & $\begin{array}{l}35 \\
50 \\
16\end{array}$ & $\begin{array}{l}36(1 \mathrm{w}) \\
25(2 \mathrm{w}) \\
20(3 \mathrm{w})\end{array}$ & $\begin{array}{l}18(8 w) \\
14(4 w) \\
35(16 w)\end{array}$ \\
\hline $25 \mathrm{~mm}$ & $\begin{array}{l}41 \\
45\end{array}$ & $\begin{array}{l}30 \\
20\end{array}$ & $\begin{array}{l}20(4 w) \\
13(4 w)\end{array}$ & \\
\hline $30 \mathrm{~mm}$ & $\begin{array}{r}-41 \\
54\end{array}$ & $\begin{array}{l}46 \\
25\end{array}$ & $\begin{array}{l}18(8 w) \\
22(1 w)\end{array}$ & $31(16 w)$ \\
\hline
\end{tabular}

が多いが，1 个月後は拡張するものが多い，吻合閉銷 により $3 \sim 4$ 週までに吻合作成前の大きさに復する. 静脉系の拡張は血管造影でみられるように吻合部未梢 大腿静脉では特に著しい，また下腹部より大腿内側に みられる皮静脉の拡張は開鎖後 $1 \sim 2$ 週までに消失 する.

心胸郭係数 (C. T. R.) については吻合口 $5 \mathrm{~mm}$, $15 \mathrm{~mm}, 25 \mathrm{~mm}$ の 3 種を作成して比較したが吻合口 の大きい例に著明な増加を認めたが開鎖により 4 週ま でに吻合作成前に復した。（図 4 ) 


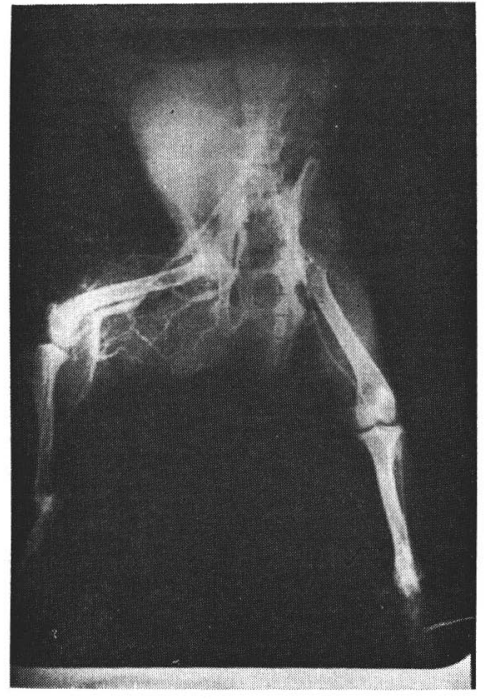

図 3 (A) 吻合作成後 1 力月

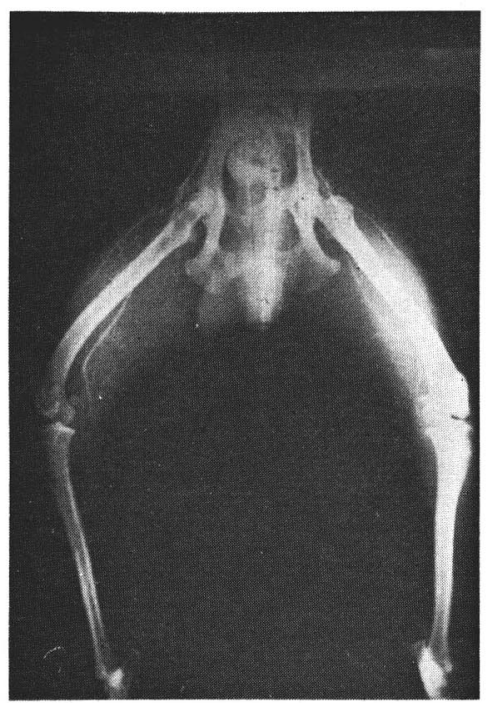

図3（B）吻合閉鎤直後

総括

吻合閉鎖により大腿動脉血流量は減少し血圧はやや 上昇する. また拡張した中枢大腿動脉は吻合開鎖後 3 〜 4 週でほぼ吻合作成前の大きさに回復する，また吻 合口の大きい例で C.T.R. の増大したものも閉鎖によ り 4 週までに吻合作成前に回復した. 動静脉吻合後に みられた豊富な小血管の陰影像は閉鎖後は非常に減少 した.

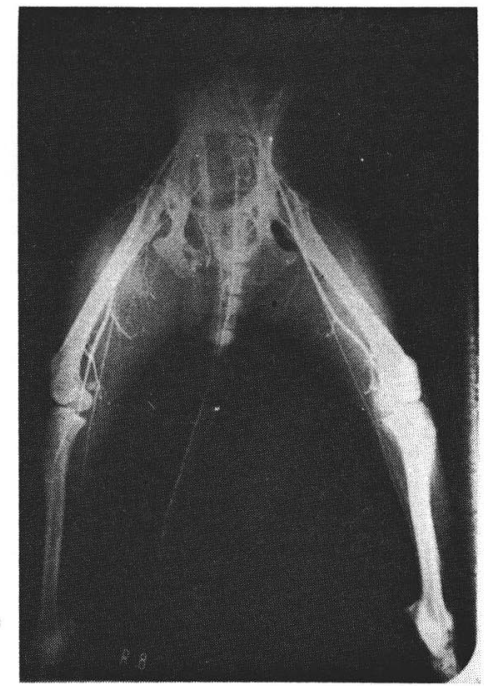

図3（C）吻合閉鎖後11週

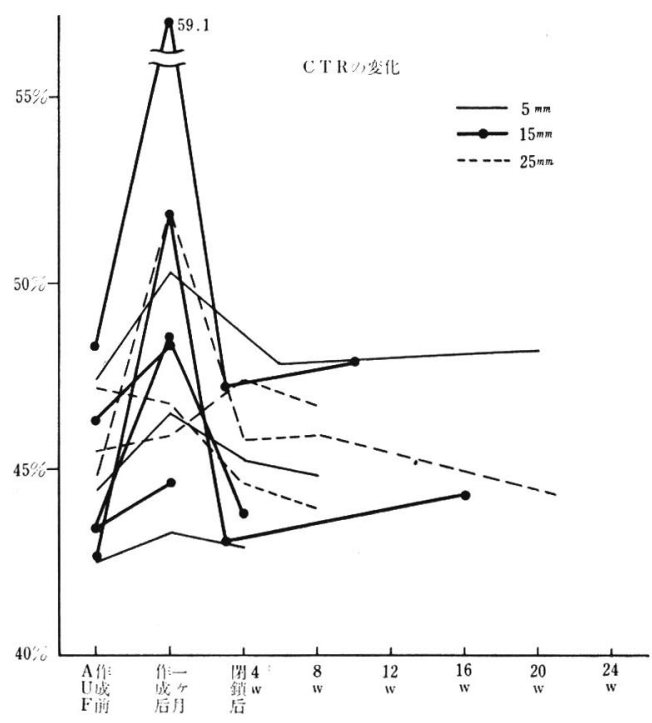

図 4

以上実験的動静脉熡閉鎖後の未梢循環系および心臟 の変動について報告したが臨床的に応用する場合問題 となるのは心臟に対する影響かと考える。吻合作成に より静脉から心臟への流入量が増加し心仕事量はふえ 脉搏数の増加, 心拡張ないし心肥大をきたすが，動静 脉㾞の吻合口の大きさ, 動静脉瘦の開口の期間, 動静 脉瘦と心淢との距離などに密接な関係がある。乙れら の点に注意して定期的な検診が必要と考える. 


\section{文献}

1）島：脚長不同とその対策, 臨床と研究. 35(7): 889, 昭33.

2）富重：動静脈瘦と骨発育, 福岡医学雑誌。59 (10).

3）冨重・他：下肢動静瘻形成の末梢循環動態と骨 発育，第41回日整会学術講演集録。339, 1968 。

4) Miller : Anatomy of the dog.

5) Booher, L. H. et al.: A Study of the collateral circulation after excision of arteris venous bistulas. Surgery. 26: 918, 1949.

6) Cohen, S. M. et al.: Cardiac output and peripheral blood blow based in auteriovenous Aneurysm. Clin. Sci. 7 : 35, 1948.

7) Robertson, R. L., Dennis, E. W. cind Elkin, D. C. : Collateral circulation in the presence of experimental arteriovenosu bistula. Surgery, $27: 1-16,1950$.

8) Hohlman, E.: Prom blems in the dynamies of blood blow. Surgery. 26: 889-917, 1949.

9) Hohlman, E.: The plysiology of an arteriovenous bistula. Amer. J. Surg. 89: 1101, 1955.

10）伊藤：骨長径成長促進機序に関する研究（第 3 報）北海道整形災室外科雑誌。7(2)：199.

\title{
最近経 験した尺骨神経麻痺
}

$\begin{array}{ccccc}\text { 九州厚生年金病院整形外科 } & & & \\ \text { 三 } & \text { 輪 } & \text { 信 } & \text { 二 } \\ \text { 䓢 } & \text { 田 } & \text { 日 } & \text { 出 } & \text { 等 } \\ \text { 清 } & \text { 水 } & \text { 万 } & \text { 喜 } & \text { 生 }\end{array}$

\section{Diagnosis and Treatment of the Delayed Ulnar Nerve Neuritis}

\author{
By \\ N. Miwa, H. Sonoda \& M. Simizu \\ Orthopedic Department of Kyushu Welfare Pension Hospital
}

Three men of sixth decade, who had hypesthesia and paresthesia at the ulnar nerve distributions and atrophy of the hand muscles were reported.

Everyone had evident osteoarthritis in the lower cervical vertebrae and in the right elbow joint.

Though osteophytic formation at the ulnar side of the trochlea was similar grade in three men, only one had paresis of the right ulnar nerve due to campression by the osteophyte.

In one of remains, surgical exposure of the right ulnar nerve showed dislocation of this nerve onto the tip of the medial epicondyle and slight cicatrical constriction at the proximal level of the epicondyle.

The last one had the history that diagnosed as delayed neuritis of the right ulnar nerve and treated with no improvement. His symptomes and signs seemed to be those of due to peripheral lesion and oblique roentgenograms revealed no narrowed intervertebral canal between the seventh cervical vertebra and first thracal vertebra. But in lower part of the pectral major muscle there exist slight muscle atrophy. Electromyography showed polyphasic motor unit voltages and giant oscillations in this portion. Moreover, myelogram revealed defect of the nerve root contour of the eighth cervical nerve.

After surgery, decompression of this nerve root was performed, immediate sensory improvement was obtained. 